\title{
A!
}

This is an electronic reprint of the original article.

This reprint may differ from the original in pagination and typographic detail.

Holland, Keiran; Eriç, R. Hürman; Taskinen, Pekka; Jokilaakso, Ari

\section{Upgrading copper slag cleaning tailings for re-use}

Published in:

Minerals Engineering

DOI:

10.1016/j.mineng.2018.12.026

Published: 15/03/2019

Document Version

Peer reviewed version

Published under the following license:

CC BY-NC-ND

Please cite the original version:

Holland, K., Eriç, R. H., Taskinen, P., \& Jokilaakso, A. (2019). Upgrading copper slag cleaning tailings for re-use. Minerals Engineering, 133, 35-42. https://doi.org/10.1016/j.mineng.2018.12.026

This material is protected by copyright and other intellectual property rights, and duplication or sale of all or part of any of the repository collections is not permitted, except that material may be duplicated by you for your research use or educational purposes in electronic or print form. You must obtain permission for any other use. Electronic or print copies may not be offered, whether for sale or otherwise to anyone who is not an authorised user. 


\title{
Upgrading copper slag cleaning tailings for re-use
}

Keiran Holland, R. Hürman Eriç ${ }^{1}$, Pekka Taskinen* \& Ari Jokilaakso

Aalto University, School of Chemical Engineering, P.O. Box 16100, 00076 Aalto (Finland)

${ }^{1}$ present address:

University of Witwatersrand, School of Chemical and Metallurgical Engineering, Johannesburg (RSA)

\begin{abstract}
Tailings from an industrial copper slag cleaning milling and flotation circuit have been pre-reduced at low temperatures, well below its melting point, using $\mathrm{CH}_{4}-\mathrm{H}_{2}-\mathrm{Ar}$ mixtures with the aim of metallizing its iron oxide component to metallic iron. The treatment carried out at $700-900{ }^{\circ} \mathrm{C}$, with a duration of up to 90 $\mathrm{min}$, indicated a complete transformation of magnetite within the first $30 \mathrm{~min}$ of the process. At the same time, significant fractions of its harmful impurities, antimony, arsenic, bismuth, lead and zinc, present as oxides in the slag were reduced from magnetite and the glassy inter-granular phase, and removed from the slag as flue dust in the process off-gas. The obtained fine slag powder with low impurity contents can be melted after the pre-reduction to synthetic rock or to fast cooled slag granules for further use.
\end{abstract}

Key words: smelting, slag utilization, reduction kinetics, volatilization, hydrocarbons

*Corresponding author; e-mail: pekka.taskinen@aalto.fi, ORCID: https://orcid.org/0000-0002-4054-952X .

\section{Introduction}

Total global mine production of copper in 2017 was 19.7 Mt (USGS 2018), the production of secondary copper 4.1 Mt (ICSG 2018), and about $20 \%$ of the primary production in 2015 was processed in hydrometallurgical circuits (USGS 2017). Global demand of copper by 2050 will at least double (EU 2016). This gives an order of magnitude for the slag generation in today's copper industry of about $45 \mathrm{Mt} / \mathrm{a}$ and in 2050 about $100 \mathrm{Mt} / \mathrm{a}$. The amount is about $1 / 3$ of the steel slag production. At the smelter sites, the slag is either in form of the primary smelting or 'furnace' slag containing $>30 \mathrm{wt}-\%$ silica, as converter slag with typically less than $28 \mathrm{wt}-\% \mathrm{SiO}_{2}$, or as a mixture of those. Most impurities of the raw materials, typically antimony, arsenic and zinc as well as the gangue minerals containing alumina, lime and alkali metal oxides deport in the furnace slag, as result of internal material circulations and the flow-sheet of the smelter (Schlesinger et al. 2011).

The iron silicate slag chemistry in copper smelting and refining is determined by the features of ternary system $\mathrm{FeO}-\mathrm{Fe}_{2} \mathrm{O}_{3}-\mathrm{SiO}_{2}$ where the oxidation degree of iron or the 'magnetite concentration' of the forming slag largely depends on the matte grade produced, and silica concentration of the slag (Mackey 1982). Typically, silica concentration in the industrial copper smelting slags is between 25 and 35 wt-\%, and if natural sand is used as the flux for the forming iron oxides, concentrations of alumina, lime, and magnesia together comprise less than $5 \mathrm{wt}$ \% (Kapusta 2004). 
The two main methods for the slag cleaning used in the copper industry today produce chemically and physically different type of slag materials. The commonly used electric furnace (EF) cleaning (Kapusta 2004) produces molten slag which can be granulated and solidified quickly into fine sand, or cast into large blocks and crushed to suitable size fractions of synthetic rock, whereas the milling and froth flotation technology, if effective always produces a very small particle size ('silt') in its tailings (Stirbanovic et al. 2011). Typical residual (total) copper concentration of the EF cleaned slag is between 0.8 and $1.2 \mathrm{wt}-\%(\mathrm{Cu})$ and in the flotation tails between 0.2 and $0.3 \mathrm{wt}$ \% (Vehviläinen et al. 2000). The mineralogy of the granulated slags is mostly glassy and the fraction of crystalline phases is small, whereas the slow cooling technology in ladles (Subramanian \& Themelis 1972) is often combined with the slag milling and flotation. It generates a coarse grain structure and a brittle slag. The residual chemically dissolved copper is also higher in the granulated EF slags (Sarrafi et al. 2004), where the stabilisation of magnetite during cooling and the final solidification of the slag, as

$$
3(\mathrm{FeO})+2\left(\mathrm{CuO}_{0.5}\right)=\mathrm{Fe}_{3} \mathrm{O}_{4}+\mathrm{Cu}^{\circ},
$$

has not been able to complete. In Eq. (1), brackets ( ) refer to chemically dissolved species in the slag and superscript ${ }^{\circ}$ to elemental form. In terms of copper recovery, it is thus quite important how the copper slag has been processed and cooled post the smelting or converting furnace, EF and prior to the milling and flotation step. Far less important, in this respect, is the actual smelting and converting technology upstream of the slag cleaning step.

The main obstacles of using cleaned copper slags as construction material, e.g., in civil engineering, include the leachability of their typical trace elements, like zinc, arsenic and antimony (Potysz et al. 2005), from the material, and a small particle size of the flotation process tailings, with a $d_{50}$ often less than $30 \mu \mathrm{m}$ (Alp et al. 2008). A small part of the slag production is used as blasting sand in shipyards (Murari et al. 2015). On the pro side of utilising such side streams of copper production is the large $\mathrm{CO}_{2}$ footprint of cement making from virgin natural minerals (Benhelal et al. 2013). Another focus has been a direct use of granulated copper slag in concrete as replacement of natural sand (Lye et al. 2015, dos Anjos et al. 2017, Prem et al. 2018).

Several studies have been published about the use of copper and other non-ferrous slags as a raw material in cement clinker making, and as a component of concrete (Shi et al. 2008, de Shepper et al. 2015, Dash et al. 2016). Their focus mostly has been on its behavior in the cement kiln as iron carrier for making the clinker, as well as in pozzolanic properties of the slag as aggregate in the concrete (Lam et al. 2011, Al-Jabri et al. 2011, Edvin et al. 2016). Relatively little attention has been paid to the leaching properties of the trace elements present in the iron silicate slags (Shanmuganathan et al. 2008), either as chemically dissolved oxide, or as tiny mechanically entrapped sulphide matte or metal particles. It is, however, clear that the cement clinker making and the highly alkaline environment of concrete affect the leaching properties of slags' elements, in a similar way as in MSW bottom slags often used for that purpose as well (Lam et al. 2011).

This study has its focus in the reduction behavior of the copper smelting slag flotation tailings at low temperatures, for transferring magnetite into metallic iron and eliminating high vapor pressure impurities into the gas phase. Thus, the subsequent $\mathrm{EF}$ melting of the pre-reduced material is a phase separation step only where the metallic fraction formed will have settled and removed from the silicate slag. After the phase separation in the molten state, the impurity depleted residual silicate slag may be cast into blocks for synthetic rock or granulated to a spherical 1-3 mm in diameter vitreous slag sand. The forming fumes rich in zinc and other low-boiling metals and oxides generate a side-stream of the pre-reduction process, and that may be treated for metals recovery or deposition in a safe way. 


\section{Experimental}

The gases used were purchased from Aga-Linde (Finland) and their purities were 99.5 vol-\% $\mathrm{CH}_{4}, 99.99 \% \mathrm{H}_{2}$ and $99.999 \%$ Ar. Their volumetric flow rates in the gas train, Fig. 1, were controlled manually using calibrated flowmeters ( Aalborg P-type, USA ) and prior to leading them into the reduction furnace the component gases were premixed at room temperature.



Figure 1. Gas train of the experimental set up (Halli 2015).

The gas mixture used in the study composed of $\mathrm{Ar}, \mathrm{H}_{2}$ and $\mathrm{CH}_{4}$ with constant volume fraction of $50 \%$ of dry argon. The methane concentrations used were 5, 10 and 15 vol- $\% \mathrm{CH}_{4}$, selected in order to avoid excessive deposition of soot during reduction. The total flow rate of gas mixture in the experiments was $800 \mathrm{~mL} / \mathrm{min}$ (STP) and the initial mass of the slag tailings was $50.5 \pm 0.5 \mathrm{~g}$ in an alumina boat ( Degussit AL23 supplied by Friatec AG, Germany ) forming a stationary bed during the reduction process.

The copper smelting slag tailings, obtained from Boliden Harjavalta copper smelter ladle-cooling and milling circuit, were dried prior to the experiments in air at $110^{\circ} \mathrm{C}$ in an oven and stored thereafter in a closed glass bottle. The sample mass was measured prior to the experiments by an analytical semi-micro balance ( Mettler Toledo AB204-S, USA ) with an accuracy of $\pm 0.05 \mathrm{mg}$. The XRF ( X-ray fluorescence spectroscopy ) analysis of the raw material was collected in Table 1. Magnetite concentration of the slag cleaning tailings, measured with the Satmagan technique (Laurila et al. 1951), was $18 \pm 0.5 \mathrm{wt}-\% \mathrm{Fe}_{3} \mathrm{O}_{4}$. Particle size distribution of the slag cleaning tailings was measured with a Mastersizer 3000 laser diffraction equipment (Malvern Instruments Ltd., UK). $3 \%$ of it was $-1 \mu \mathrm{m}, 29 \%-10 \mu \mathrm{m}, 80 \%-50 \mu \mathrm{m}$ and $100 \%-185 \mu \mathrm{m}$.

Table 1. Chemical composition of the copper slag tails (XRF) used in the experiments.

\begin{tabular}{ccc} 
Substance & Concentration & Unit \\
\hline $\mathrm{Fe}$ & 40.8 & $\mathrm{wt} \%$ \\
$\mathrm{SiO}_{2}$ & 31.9 & $\mathrm{wt} \%$ \\
$\mathrm{Zn}$ & 2.6 & $\mathrm{wt} \%$ \\
$\mathrm{~Pb}$ & 0.63 & $\mathrm{wt} \%$ \\
$\mathrm{Cu}$ & 0.28 & $\mathrm{wt}-\%$ \\
$\mathrm{As}$ & 0.18 & $\mathrm{wt} \%$ \\
$\mathrm{Ni}$ & 0.14 & $\mathrm{wt}-\%$ \\
$\mathrm{~S}$ & 0.13 & $\mathrm{wt} \%$ \\
$\mathrm{Co}$ & 0.08 & $\mathrm{wt} \%$ \\
$\mathrm{Sb}$ & 0.044 & $\mathrm{wt} \%$ \\
\hline
\end{tabular}

The experimental procedure included inserting the sample slowly into the hot zone of a horizontal laboratory tube furnace ( Heraeus RoS 4/50, Germany ) in flowing argon, and switching on the reduction 
gas mixture when the sample was located in isothermal conditions. After the reduction period, the boat and sample was removed quickly to the water-cooled brass furnace head. This gives us an uncertainty for the time scale of less than $\pm 1 \mathrm{~min}$. The true sample temperature was measured with a calibrated $\mathrm{Pt} / \mathrm{Pt} 10 \mathrm{Rh}$ thermocouple ( Johnson-Matthey, UK ) with an accuracy of $\pm 5^{\circ} \mathrm{C}$.

After cooling, the sample was divided into smaller portions for chemical and microstructure analyses using SEM/EDS ( scanning electron microscopy/energy dispersive spectroscopy ). The SEM-EDS analyses were used to determine the chemical changes in the reduction products and their phases. A LEO 1450 VP SEM ( Carl Zeiss AG, Germany ), X-max 50 EDS analyser and INCA software by Oxford Instruments (UK) were used. The accelerating voltage used in SEM was $15 \mathrm{keV}$, and the electron beam current though the sample between $50 \mathrm{nA}$ and $65 \mathrm{nA}$ was measured. ZAF correction (Pouchou \& Pichoir 1986) by the INCA software was applied to the raw EDS data. Prior to SEM-EDS observations, the samples were cast into epoxy, grinded and polished with standard wet methods, and coated with carbon using a Leica EM SDC050 sputter coater (Leica Mikrosysteme GmbH, Austria).

Selected samples were analysed post pre-reduction using ICP-OES technique ( Inductively Coupled PlasmaOptical Emission Spectroscopy ) concerning their total concentrations of trace elements $\mathrm{As}, \mathrm{Bi}, \mathrm{Pb}, \mathrm{Sb}$ and $\mathrm{Zn}$. Their detection limits were 10, 0.2, 10, 20 and $2 \mathrm{ppm}(\mathrm{mg} / \mathrm{kg})$, respectively. The XRF data of the initial slag composition in Table 1 is in good agreement with the ICP-OES measurements.

\section{Results}

The reduction of oxides by methane proceeds at high temperatures by decomposing $\mathrm{CH}_{4}(\mathrm{~g})$ on oxide and metal surfaces as

$$
\mathrm{MeO}_{x}+\mathrm{CH}_{4}(\mathrm{~g})=(1-\mathrm{x}) \mathrm{C}(\mathrm{s})+\mathrm{xCO}(\mathrm{g})+2 \mathrm{H}_{2}(\mathrm{~g})+\mathrm{Me},
$$

and at low temperatures, but few hundred degrees above the decomposition temperature of pure $1 \mathrm{~atm}$ methane, the decomposition is kinetically slow and the formation of soot, $C(\mathrm{~s})$, is slight or even absent, as

$$
\mathrm{MeO}_{x}+x \mathrm{CH}_{4}(\mathrm{~g})=x \mathrm{CO}(\mathrm{g})+2 \mathrm{xH}_{2}(\mathrm{~g})+\mathrm{Me}
$$

The contribution of hydrogen in the reduction of iron oxides is not known. Many literature sources (e.g., de Campos \& Eric 2006, Ostrowski et al. 2006, Halli et al. 2016) refer gaseous methane (natural gas) as a more powerful reductant than pure gaseous hydrogen or solid carbon alone. This has been explained as consequence of the cracking reaction of $\mathrm{CH}_{4}$ where locally the chemical activity of forming carbon, due to slow decomposition kinetics of methane at elevated temperatures, exceeds that of the stable reaction:

$$
\mathrm{CH}_{4}(\mathrm{~g})=\mathrm{C}(\mathrm{s})+2 \mathrm{H}_{2}(\mathrm{~g}) \text {, }
$$

or as the generating nano sized soot on the oxide surface is kinetically more reactive and can even reduce various metal oxides further to carbides instead of metals, including, e.g., titanium and vanadium, at low temperatures, around $1000-1100^{\circ} \mathrm{C}$ (Halli et al. 2016).

The gravimetric reduction degree data in different $\mathrm{P}\left(\mathrm{CH}_{4}\right)$ atmospheres, as a function of reduction time $(\tau)$ obtained in this study is shown in Fig 2. The reduction degree in Fig. 2 is the fraction of decreased mass 
divided by total initial mass of the sample. The scatter of the mass loss in different gas compositions with 515 vol-\% $\mathrm{CH}_{4}$ during the reduction at each temperature was within the statistical error of the observations, given as error bars in Fig. 2.

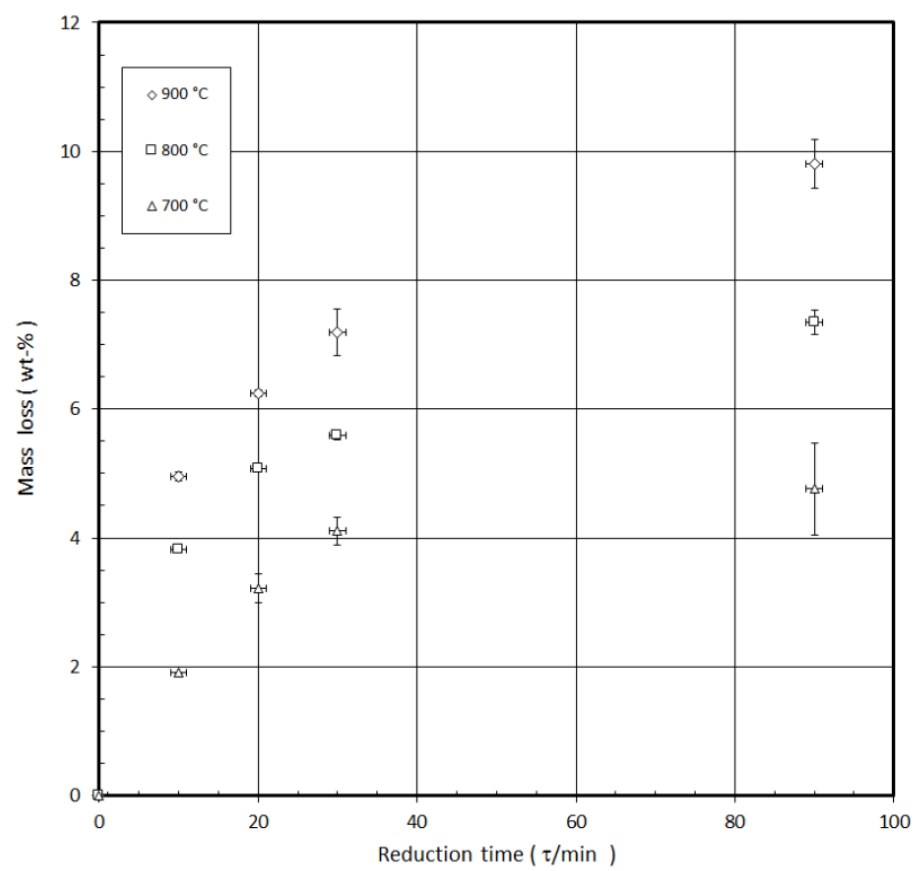

Figure 2. Gravimetric reduction rate plots of the copper smelting slag tailings at $700-900{ }^{\circ} \mathrm{C}$ in hydrogen-methane mixtures.

Determining the relative reduction degree from the gravimetric data is not possible, as we do not know which phases in the slag react with methane and what is the product of that reaction. Copper slag cleaning tails reduction mechanism is more complex than that of a single oxide, as it is a composite of crystalline magnetite ('spinel', $\left.\mathrm{Fe}_{3} \mathrm{O}_{4}\right)$ and fayalite $\left(\mathrm{Fe}_{2} \mathrm{SiO}_{4}\right)$ phases embedded in the glassy, inter-granular matrix phase formed in the final solidification the industrial slag in the slow ladle cooling step (Subramanian \& Themelis 1972). The small particle size of less than $d_{50}=25 \mu \mathrm{m}$ suggests that the above phases, at least partially, are exposed to the reduction atmosphere and its $\mathrm{CH}_{4}(\mathrm{~g})$ during pre-reduction, even if in the slag milling they have not been completely liberated to separate particles of their own.

\subsection{Microstructure development}

A SEM micrograph set in Fig. 3 upon the effect of temperature at $700-900{ }^{\circ} \mathrm{C}$ on microstructure shows also an impression of the original particle size of the slag used as well as the main phases present (Fig. 3(a)). Some particles in the polished section micrographs are of almost pure magnetite (light grey), whereas the long fayalite grains (grey) exist typically together with the inter-granular glass (dark grey). Occasional, small $(<5 \mu \mathrm{m})$ matte and copper droplets (white) were entrapped between arms of fayalite crystals, as shown in Fig. 4(a). The formation of metal layers and separate grains (white in (b), (c) and (d)) is obviously a consequence of reactions of magnetite with the reduction gas.

The metallization at low temperatures also generates porosity in the reacting magnetite particles and their original phase volumes shrink, due to the smaller molar volume of iron compared to that of magnetite. This feature can be seen in detail in Fig. 5. Evolution of the pre-reduced microstructure of the slag as a function of treatment time at $800^{\circ} \mathrm{C}$ is shown in the set of micrographs of Figs. $4(\mathrm{a})$-(d). 


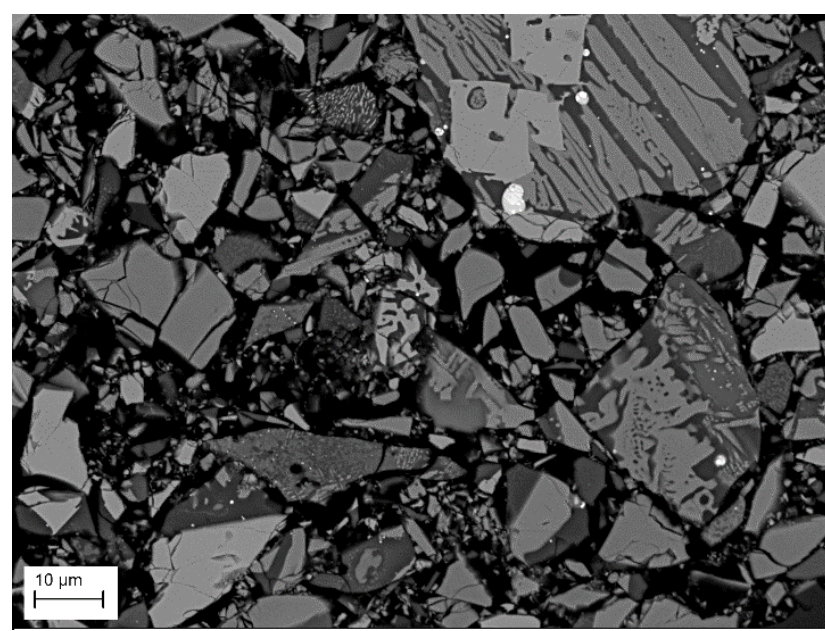

(a)

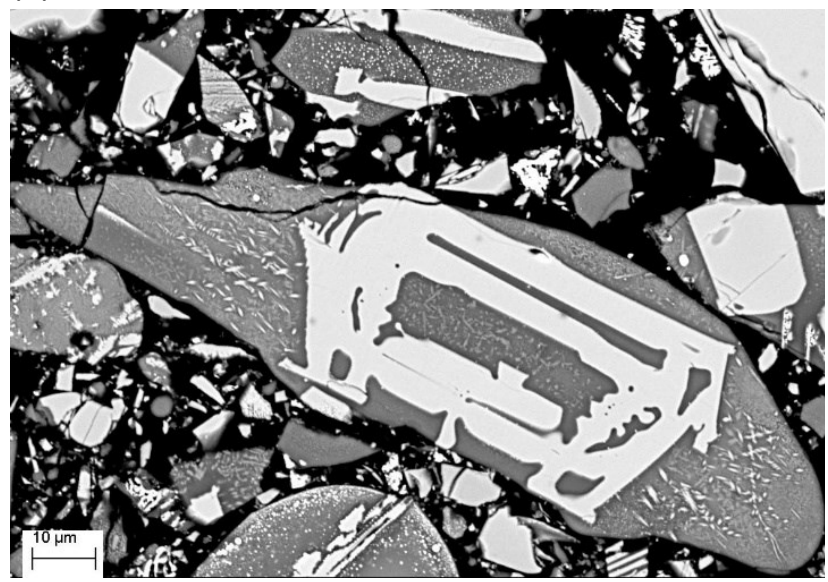

(c)

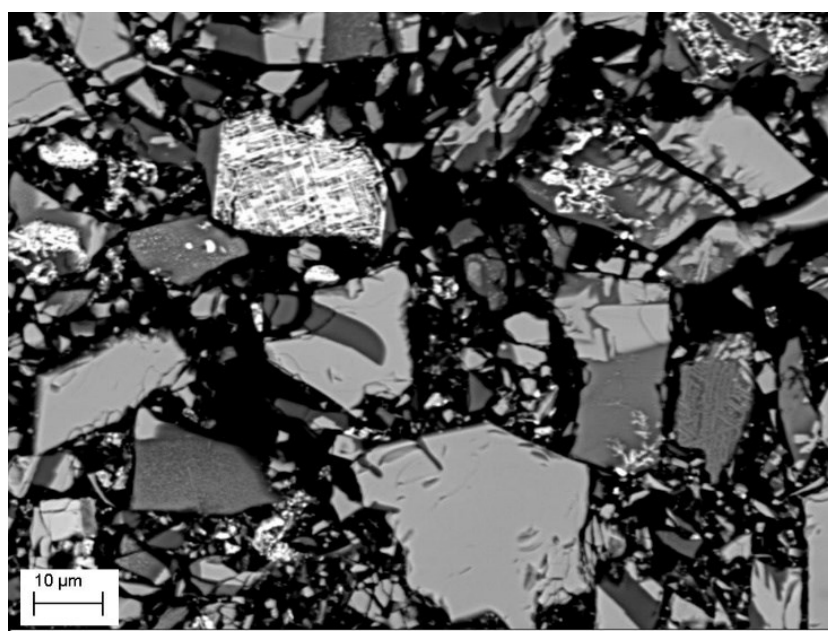

(b)

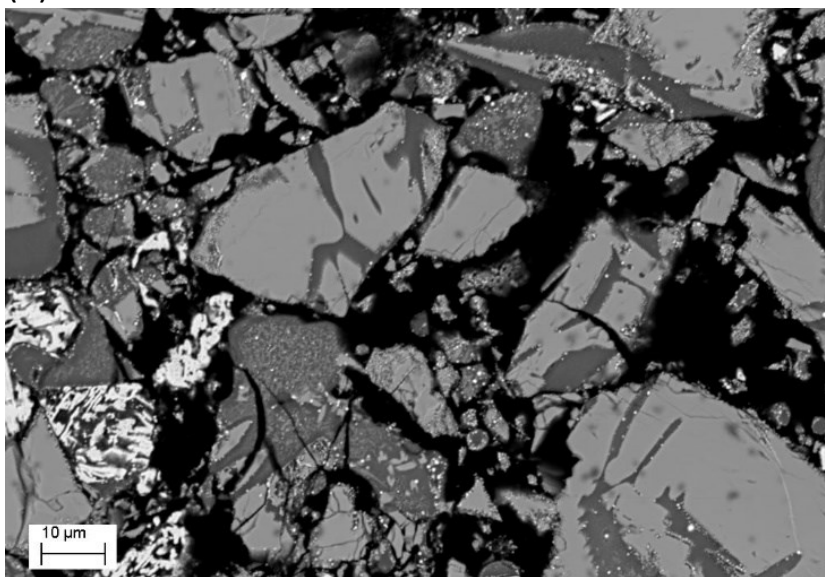

(d)

Figure 3. Micrographs of the raw material (a) and the end products at 700 (b), 800 (c) and $900{ }^{\circ} \mathrm{C}$ (d) after 90 min in 10 vol- $\% \mathrm{CH}_{4}+40$ vol- $\% \mathrm{H}_{2}$-Ar mixtures ( magnification $\times 2000$ ).

A comparison of the glassy, inter-granular phase at different temperatures suggests that very small $(<1$ $\mu \mathrm{m})$ metal precipitates appear on its grain boundaries with the fayalite grains when most magnetite in the slag has been reduced, after $\approx 30 \mathrm{~min}$ processing time depending on temperature. The sizes of those precipitates are, however, so small that no EDS analysis was possible for confirming their chemistries.

As Figs. 3 - 5 indicate, the slag particles retain well their original shapes and sizes in the tailings during the $\mathrm{CH}_{4}$ reduction. No significant neck growth could be seen between the slag grains either, even if the slag, by visual observations, was clearly sintered to a brittle cake after the treatment for $90 \mathrm{~min}$ at $900{ }^{\circ} \mathrm{C}$ in all atmospheres. No changes in the crystal shapes either can be clearly seen in the fayalite precipitates or in the inter-granular, glassy matrix. 


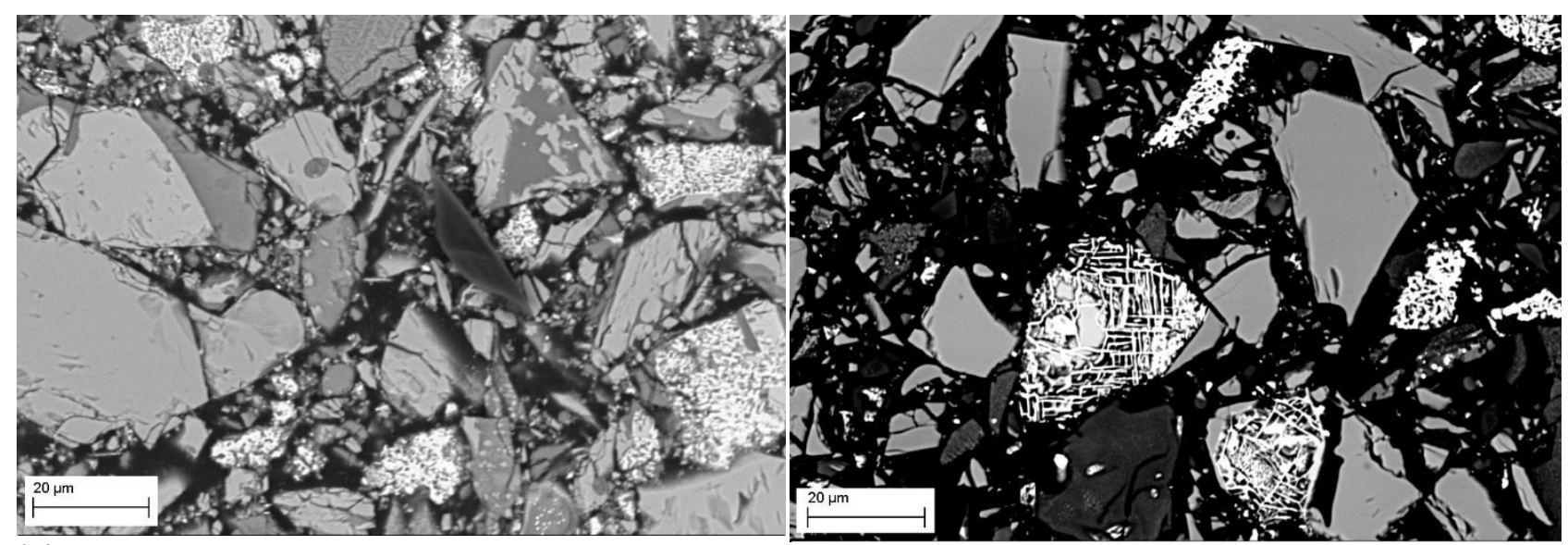

(a)

(b)

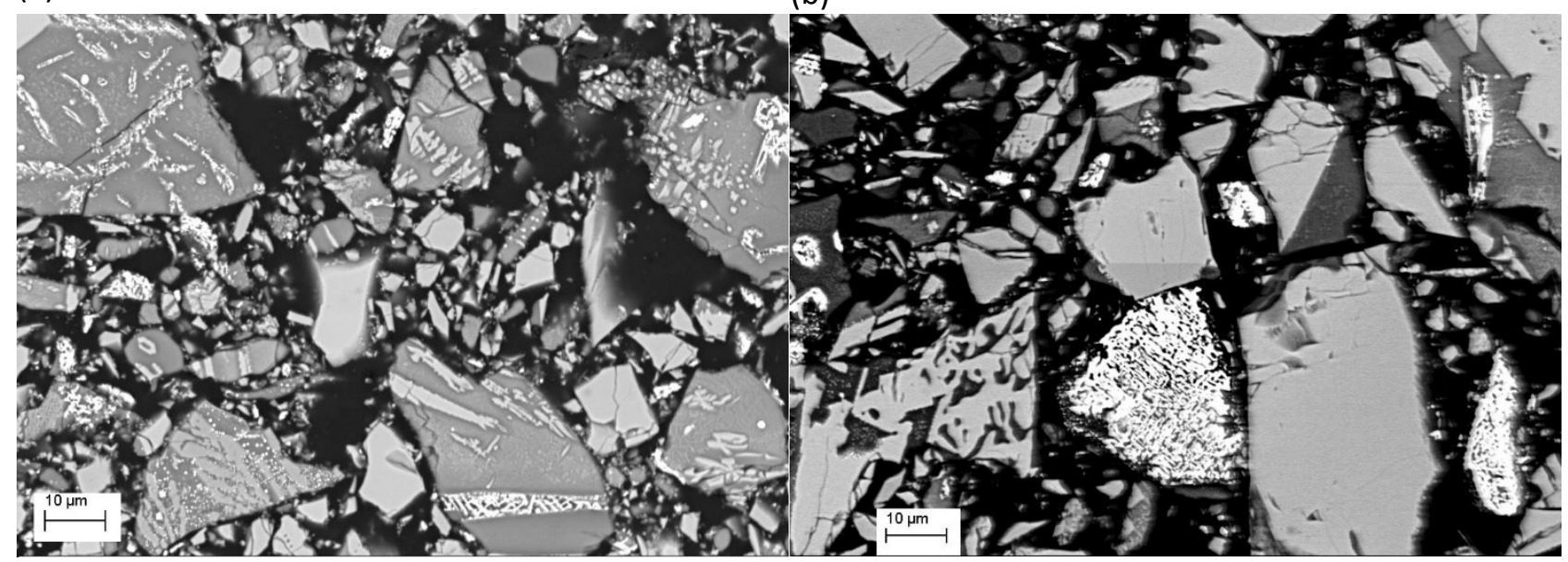

(c)

(d)

Figure 4. Evolution of the microstructure as a function of reduction time in 5 vol- $\% \mathrm{CH}_{4}$ at $800{ }^{\circ} \mathrm{C}: 10 \mathrm{~min}$ (a), $20 \mathrm{~min}$ (b), $30 \mathrm{~min}$ (c) and $90 \mathrm{~min}$ (d) ( magnification $\times 2000$ ).

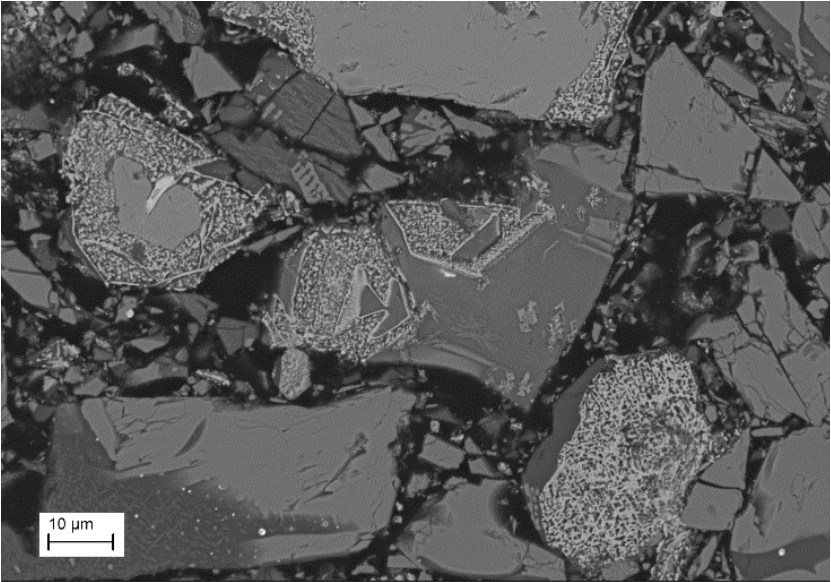

(a)

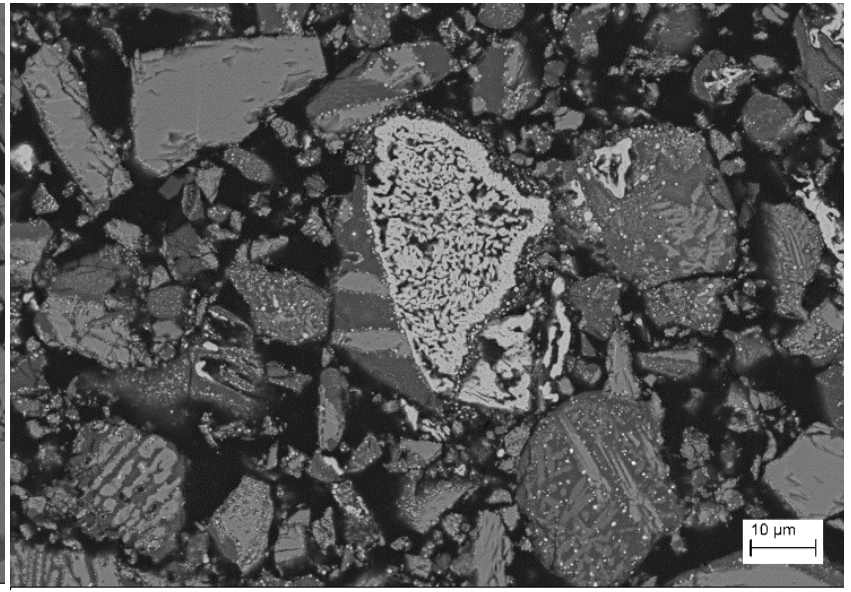

(b)

Figure 5. Porous iron metal agglomerates formed from magnetite grains in the slag tailings at $700{ }^{\circ} \mathrm{C}$ after 30 min reduction time with 15 vol- $\% \mathrm{CH}_{4}$ (a) and at $900{ }^{\circ} \mathrm{C}$ with 15 vol- $\% \mathrm{CH}_{4}$ after $90 \mathrm{~min}$ (b) ( magnification $\times 2000$ ). 


\subsection{Metallisation}

Magnetite concentration of the used slag cleaning tails according to the chemical analysis was $18 \mathrm{wt}-\%$ $( \pm 0.5 \mathrm{wt}-\%)$. If stoichiometric magnetite is fully reduced to metallic iron in the treatment, the weight loss is $27.64 \%$. In case of the present slag cleaning tailings, this means a total mass loss of $4.9(8) \mathrm{wt}-\%$.

At $700{ }^{\circ} \mathrm{C}$ treatment temperature, the observed mass loss was close to that calculated for reduction of all magnetite in the slag, but at 800 as well as at $900^{\circ} \mathrm{C}$ after 90 min treatment time, the experimental mass loss was up to twice of that calculated from the complete magnetite reduction alone, see Fig. 2 . Thus, the detailed EDS data of all precipitates of the slag were collected from the polished sections. In addition to oxygen bound with iron oxides in the magnetite phase, the observations indicate that also other phases of the slag have either been partially reduced to metal, or removed from the solid slag to the flowing gas stream in the furnace.

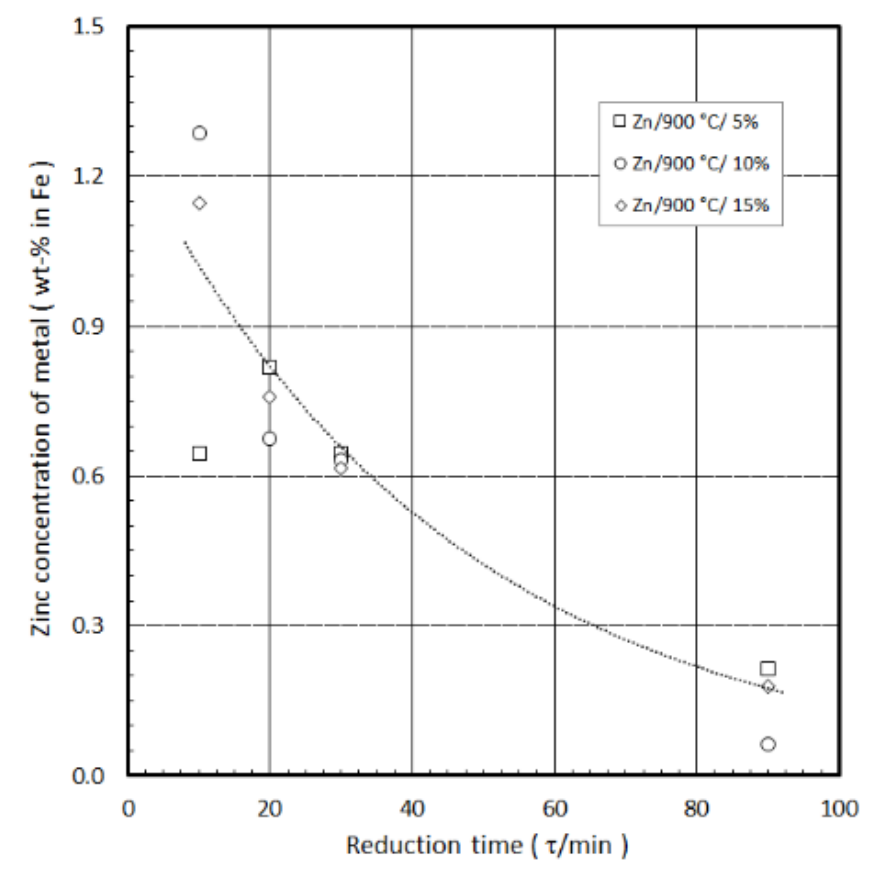

Figure 6. Measured zinc concentration of the iron phase at $900^{\circ} \mathrm{C}$ as a function of reduction time in various $\mathrm{Ar}-\mathrm{H}_{2}-\mathrm{CH}_{4}$ atmospheres; the trend line ( $\left.\cdots\right)$ was drawn using all the experimental points with $5-15$ vol-\% $\mathrm{CH}_{4}$.

The globular iron precipitates forming at $700^{\circ} \mathrm{C}$ before $30 \mathrm{~min}$ in all the gas mixtures were too small to be analysed by EDS. At 800 and $900^{\circ} \mathrm{C}$, the grain growth of iron precipitates allowed their composition to be measured already after the 10 min reduction period. The forming metallic iron-rich ( $>95 \mathrm{wt}-\% \mathrm{Fe}$ ) phase contained some copper and zinc so that its zinc concentration at $900{ }^{\circ} \mathrm{C}$ clearly decreased as a function of reduction time, see Fig. 6 . This behavior indicates that zinc vaporizes from the slag as metal vapour at temperatures close to and above its boiling point ( $906.85^{\circ} \mathrm{C}$ (Hultgren et al. 1973) ) and not as zinc oxide, which has a low vapour pressure below $1000^{\circ} \mathrm{C}$.

The overall compositions of the fayalite ( $(\mathrm{Fe}, \mathrm{Mg}, \mathrm{Zn})_{2} \mathrm{SiO}_{4}$, based on the EDS data ) grains proved essentially constant at all process temperatures and in the used reduction conditions of different methane concentrations as a function of time. The high-temperature behavior of the fayalite crystals at $900{ }^{\circ} \mathrm{C}$ as a function of time is shown in Fig. 7. The primary EDS data were calculated to oxide components assuming all iron as divalent ferrous oxide in the iron orthosilicate. The solubilities of zinc oxide and magnesium oxide in 
fayalite were 4-5 wt-\% MeO which are close to the initial values generated in the slow cooling process and measured from the as received slag cleaning tailings. Here iron was estimated as divalent oxide ( $\mathrm{FeO}$ ) from the elemental EDS data.

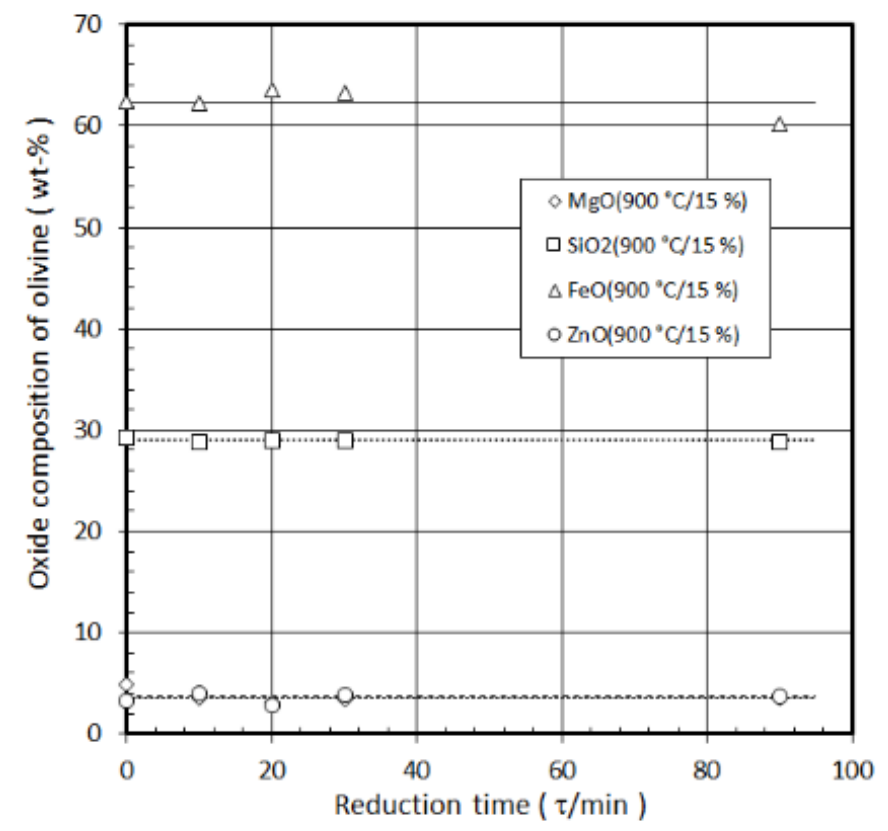

Figure 7. The oxide composition of fayalite during reduction at $900{ }^{\circ} \mathrm{C}$ in $15 \mathrm{vol}-\% \mathrm{CH}_{4}$ as a function of time; the time zero represents the composition data of the as received slag cleaning flotation tailings.

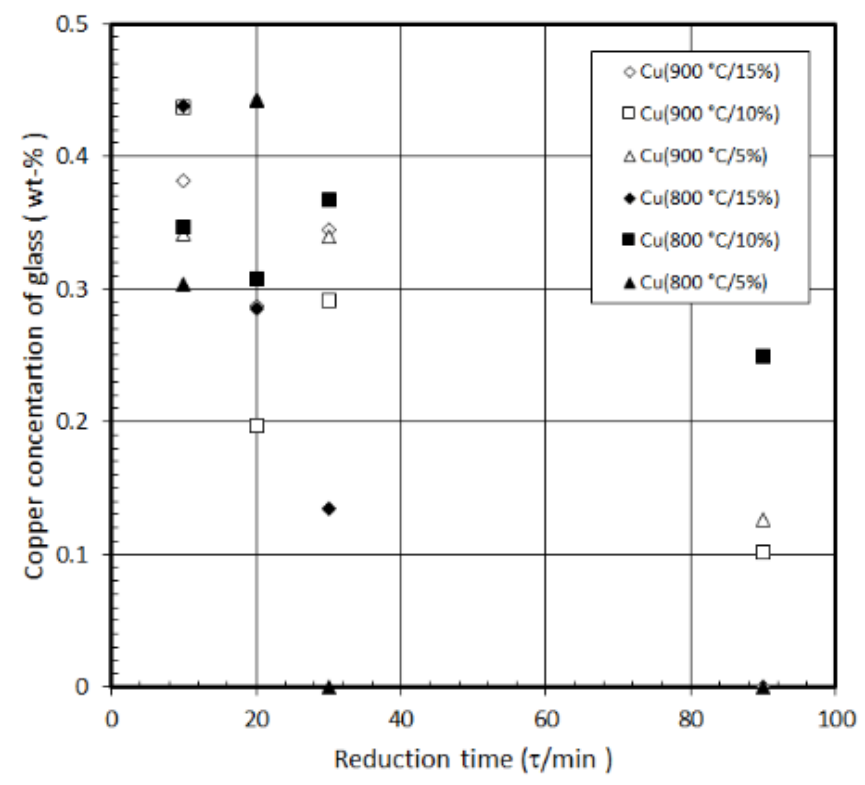

Figure 8. The removal of copper (oxide) traces from the intergranular, glassy matrix along with time.

Thus, no major re-arrangements of the components and diffusional materials transport occurred between fayalite and the surrounding glassy silicate phase during reduction. A small reduction in lead concentration of the glassy, intergranular phase may be found, but the analytical scatter of the EDS data was so large that no firm conclusions can be drawn. The experimental lead concentrations measured at 800 and $900{ }^{\circ} \mathrm{C}$ treatment temperatures in the gas mixture compositions with $5-15$ vol- $\% \mathrm{CH}_{4}$ were collected in Fig. 9. 


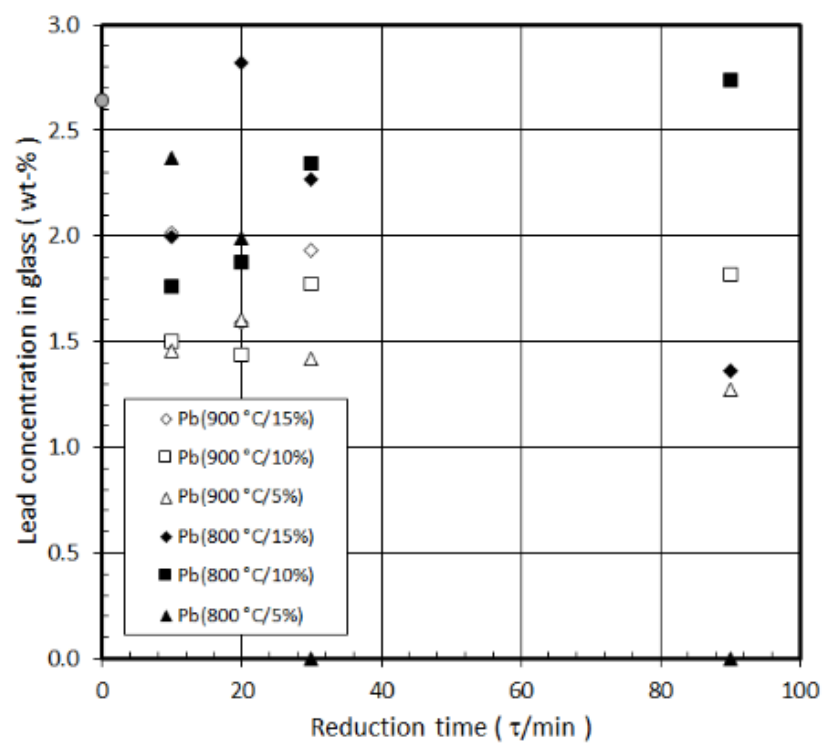

Figure 9. Lead concentration of the glassy intergranular phase after reduction treatments at 800 and $900{ }^{\circ} \mathrm{C}$ in $5-15$ vol- $\% \mathrm{CH}_{4}$ gas mixtures.

Formation of metal in the glassy interganular matrix of the slag was already identified in the microstructure observations by SEM, as shown in Fig. 5(b). It is therefore obvious that the small metal globules seen in the inter-granular glass are copper nuclei that have not been able to grow in rigid matrix of the solid oxide, and thus the chemically dissolved copper oxide content of the slag has been further transformed to metallic copper in the $\mathrm{CH}_{4}$ pre-reduction treatment.

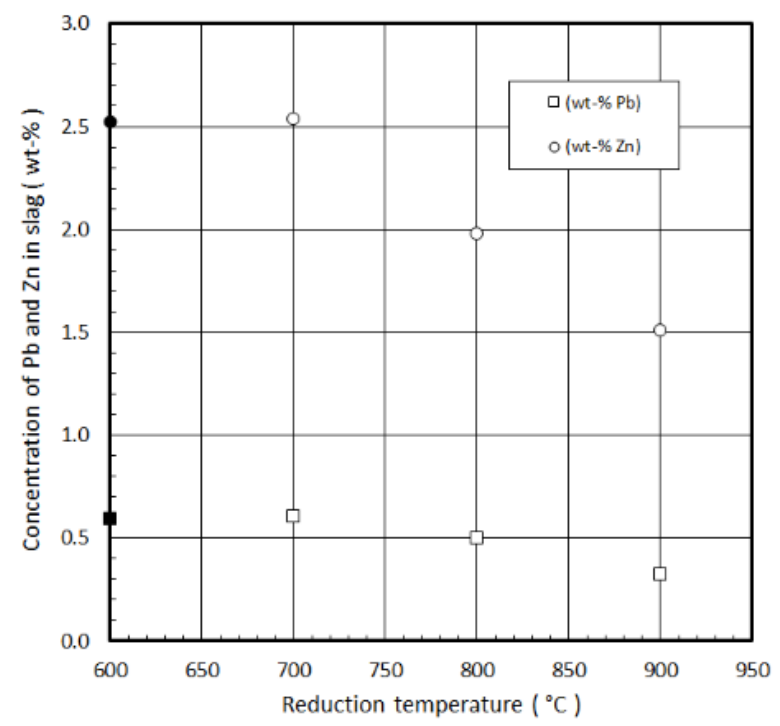

Figure 10. Concentrations of lead and zinc in the slag as a function of reduction temperature (90 min); the points at $600{ }^{\circ} \mathrm{C}$ show the concentrations of the initial slag tailings.

Fig. 10 shows the average concentrations of lead and zinc in the slag tailings after 90 min reduction at $700-$ $900{ }^{\circ} \mathrm{C}$. The results in all studied atmospheres, at each temperature, were in good agreement with each other and thus, the average value was reproduced to the graph. The first black symbol on the left indicates the $\mathrm{Pb} / \mathrm{Zn}$ impurity concentrations in the slag tailings analysed in the same time as the reduced slags. After 90 min reduction zinc concentration dropped by one wt-\% in the treatment, whereas that of lead was 
lowered to half. The behavior of bismuth is presented in Fig. 11. Its concentration at $900{ }^{\circ} \mathrm{C}$ after $90 \mathrm{~min}$ was only $20 \%$ of the original. Arsenic concentration after 90 min treatment at all temperatures was constant, and only about $10 \%$ of the original.

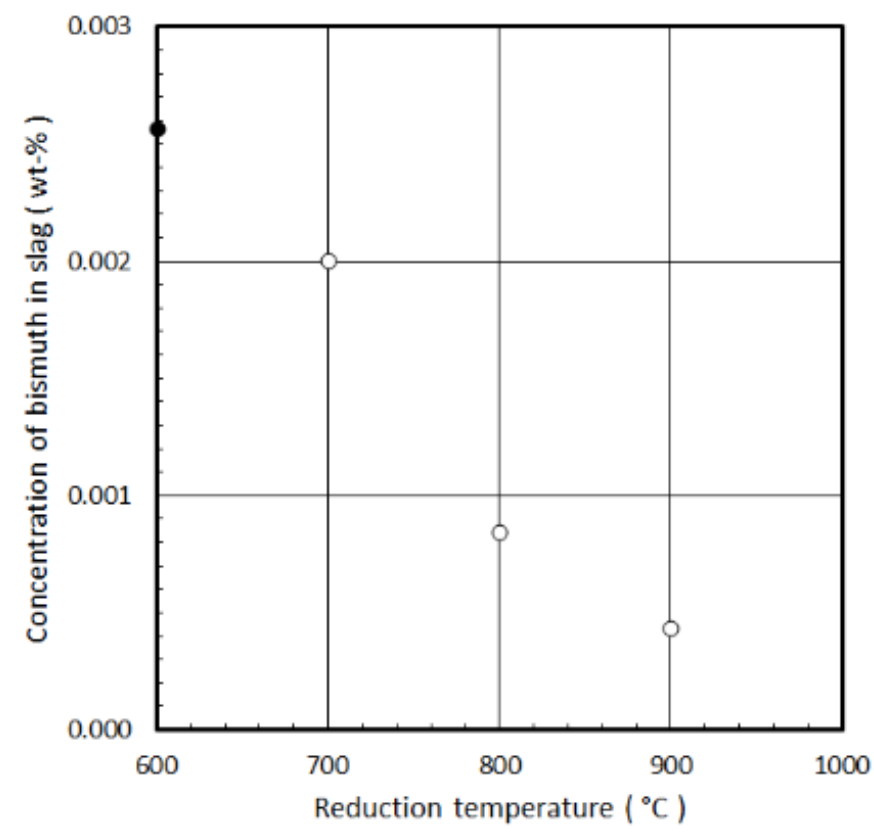

Figure 11. The behavior of bismuth in the $\mathrm{CH}_{4}$-reduction treatment as a function of temperature.

\section{Conclusions}

Direct reduction of copper smelting slags in the molten state results in end points of the process with more than $0.5 \mathrm{wt}-\%$ copper, and typically leaving more than $1 \mathrm{wt}$ \% zinc and lead (oxides) in the reduced discard slag. Some hazardous trace elements, like antimony, arsenic and bismuth, do not reduce down to nonharmful concentrations, largely due to thermodynamic reasons of the cleaning process (Coursol et al. 2012). There were earlier attempts to purify copper smelting slags from leachable elements post the actual slag cleaning operations, in the molten state, using traditional reductants such as coke and hydrogen, but also with reactive metals (e.g., Long et al. 2012, Heo et al. 2016, Lee et al. 2016 and Sarfo et al. 2017).

The present approach is fundamentally different from the earlier attempts mentioned above, as its processing environment represents a much lower temperature and thus different driving forces for the reduction reactions of various impurity oxides. Also the conditions for various mass transfer processes in the slag and in the reducing medium are different, due to the small length scales in the very fine, and high surface area slag cleaning tailings.

\subsection{Metallisation}

The current results suggest that the entire magnetite content of the copper slag cleaning tailings is reduced to metallic iron already within the first $30 \mathrm{~min}$ of the $\mathrm{CH}_{4}$ reduction process at $700{ }^{\circ} \mathrm{C}$, effectively in all gas mixtures containing 5 to $15 \mathrm{vol}-\%$ methane. Due to the small methane concentration in the process gas, $5-$ $15 \mathrm{vol}-\%$, no soot formation took place in the studied temperature range of $700-900^{\circ} \mathrm{C}$. The role of hydrogen in the reduction gas of $35-45 \mathrm{vol}-\% \mathrm{H}_{2}$ could not be estimated or isolated from the present kinetic data. 
The empirical temperature of sintering start ( i.e. the minimum sintering temperature ) for fine iron powders is around $600{ }^{\circ} \mathrm{C}$ (Zhong et al. 2012) explaining the grain growth of forming iron and the obvious densification of the surfaces of reducing magnetite grains in the studied temperature range $700-900{ }^{\circ} \mathrm{C}$, as shown in Fig. 5(b). That value is in good correlation with the Tammann temperature of metallic iron ( $\mathrm{T}_{\mathrm{mp}}(\mathrm{Fe}) / 2=633^{\circ} \mathrm{C}$ ) above which temperature bulk diffusion becomes the dominant mechanism of mass transport in the solid state (Dharanipragada et al. 2016).

\subsection{Elimination of impurities}

A significant fraction of the slag's impurities and chemically dissolved trace elements was removed during the methane reduction treatment, along with the metallization of iron oxides from the magnetite precipitates. The phenomenon is obviously a consequence of the fine, high specific area slag cleaning tailings powder ('silt'), which allows the gas good access to individual phases of the slag.

If the pre-reduction on industrial scale will be carried out in a rotary kiln, the gas-solids phase contact is improved from the stationary bed treatment of the present study, and vaporization of the impurities will be more effective than in the current laboratory scale treatment. A moderate treatment temperature, thus, results in unrestricted and relatively effective vaporization of volatile impurities, as they are not trapped behind sintering and densifying metal barriers of reducing magnetite crystals during the pre-treatment.

Purity of the slag tailings post the pre-reduction indicates significant removal of volatile harmful impurities, including lead, zinc and arsenic, from the slag cleaning tailings. Thus it makes the tailings less prone to releasing metals in the leaching tests required to confirm the safe use of the material.

\section{Summary}

The study presents a novel concept for treating copper slag cleaning tailings prior to melting and producing synthetic rock for construction industry. The copper smelting and refining slags represent globally a significant unused volume of potential aggregate material and will replace natural rock and sand in various end uses of concrete where the high density is not a problem. The pre-reduction by lean $\mathrm{CH}_{4}$ mixtures may be a feasible option for upgrading copper slags for re-use, even if the contribution of hydrogen as its decomposition product in the reduction kinetics was not possible to separate within the present data.

The smelting option after pre-reduction and use of the reduction product as pre-heated charge directly to $\mathrm{EF}$ for energy saving purpose is the obvious arrangement of the industrial slag processing flow sheet. That will also ensure that no metallised fractions in the pre-reduced product are oxidized and transferred back to the slag, and contaminate it.

\section{Acknowledgements}

The authors are indebted to Tekes for financial support of the study, as a sub-project of Fidipro program "Sustainable Production of Ferroalloys" (research grant \#40202/13) and Boliden Harjavalta for providing the raw materials as well as for the chemical analyses. The particle size determination by Mr Kamran Khalid for the raw material is kindly acknowledged. 


\section{List of references:}

Alp I., Deveci H., Süngün H. 2008. Utilisation of flotation wastes of copper slag as raw material in cement production. J. Haz. Mater., vol. 159 (2), 390-395.

Dos Anjos M.A., Sales A.T., Andrade N. 2017. Blasted copper slag as fine aggregate in Portland cement concrete. J. Environm. Managem., vol. 196 (1), 607-613.

Benhelal E., Zahedi G., Shamsaei E., Bahadori A. 2013. Global strategies and potentials to curb $\mathrm{CO}_{2}$ emissions in cement industry. J. Clean. Prod., vol. 51 (1), 142-161.

De Campos M., Eriç R.H. 2006. Reduction behaviour of chromite in the presence of a hydrocarbon gas. In: Sohn International Symposium, vol. 1 (Eds. F. Kongoli \& R. Reddy). TMS, Warrendale (PA), p. 613-621.

Coursol P., Cardona N., Mackey P., Bell S., Davis B. 2012. Minimization of copper losses in copper smelting slag during electric furnace treatment. JOM, vol. 64 (11), 1305-1313.

Dash M.K., Patro S.K., Rath A.K. 2016. Sustainable use of industrial waste as partial replacement of fin aggregate for preparation of concrete - A review. Int. J. Sust. Built Environm., vol. 5 (2), 484-516.

Dahanipragada N.V., Meledina M., Galvita V.V., Poelman H., Turner S., Van Tendeloo G., Detavernier C., Marin G. 2016. Deactivation study of $\mathrm{Fe}_{2} \mathrm{O}_{3}-\mathrm{CaO}_{2}$ during redox cycles for $\mathrm{CO}$ production from $\mathrm{CO}_{2}$. Ind. Eng. Chem. Res., vol. 55 (20), 5911-5922.

Edwin R.S., De Schepper M., Gruyaert E., De Belie N. 2016. Effect of secondary copper slag as cementitious material in ultra-high performance mortar. Constr. Build. Mater., vol. 119, 31-44.

EU 2016. Science for Environment Policy, 16 Sept. (470) [accessed at June 2018:

http://ec.europa.eu/environment/integration/research/newsalert/pdf/copper demand increase up to 3 41pc 2050 470na1 en.pdf ].

Halli P. 2015. Solid state reduction of vanadium containing Mustavaara titano-magnetite concentrate. MSc thesis, Aalto University, Espoo, 175 p.

Halli P., Taskinen P., Eriç R.H. 2016. Reduction behaviour of titanium and vanadium containing iron ore with methane. In: Scanmet V Internat. Conf. CD-ROM. SWEREA (MEFOS), Luleå (Sweden), p. 1-12.

Heo J., Chung Y., Park J. 2016. Recovery of iron and removal of hazardous elements from waste copper slag via a novel aluminothermic smelting reduction (ASR) process. J. Clean. Prod., vol. 137, 777-787.

Hultgren R., Desai P., Hawkins D., Gleiser M., Kelley K., Wagman D. 1973. Selected Values of the Thermodynamic Properties of the Elements. ASM, Metals Park (OH), p. 571.

ICSG 2018: World Refined Copper Production and Usage Trends. International Copper Study Group, 2018 [accessed on May 4, at: http://www.icsg.org ].

Al-Jabri K.S., Al-Saidy A.H., Taha R. 2011. Effect of copper slag as a fine aggregate on the properties of cement mortars and concrete. Constr. Build. Mater., vol. 25 (2), 933-938.

Kapusta J. 2004. JOM World Nonferrous Smelters Survey, Part I: Copper. JOM, vol. 56 (7), 21-27. 
Lam C.H., Barford J.P., McKay G. 2011. Utilization of municipal solid waste incineration ash in Portland cement clinker. Clean Techn. Environm. Policy, vol. 13 (4), 607-615.

Laurila E., Jäntti O. \& Hukki R. 1951. Magnetic and Chemical Analyses of Ores and Mill Products Containing Magnetite and IImenite. Trans. AIME, vol. 190 (Sept.), 797-802.

Lee T., Joo S., Nersisyan H., Kong M., Lee J., Park K., Lee J. 2016. Reduction kinetics of zinc powder from brass converter slag by pyrometallurgical method using hydrogen gas. KONA Powder and Particle J., vol. 33 (1), 278-286.

Long T., Palacios J., Sanches M., Miki T., Sasaki Y., Hino M. 2012. Recovery of molybdenum from copper slags. ISIJ Int., vol. 52 (7), 1211-1216.

Lye C., Koh S., Mangabhai R., Dhir 2014. Use of copper slag and washed copper slag as sand in concrete: a state-of-the-art review. Magazine Concr. Res., vol. 67 (12), 665-679.

Mackey P. 1982. The Physical Chemistry of Copper Smelting Slags-A Review. Can. Metall. Q., vol. 21 (3), 221-260.

Murari K., Siddique R., Jain K. 2015. Use of waste copper slag, a sustainable material. J. Mater. Cycles Waste Manag., vol. 17 (1), 13-26.

Ostrowski O., Zhang G. 2006. Reduction and carburization of metal oxides by methane-containing gas. AlChE Journal, vol. 52 (1), 300-310.

Potysz A., van Hullenbusch E.D., Kierczak J., Grybos M., Piet N.L., Guibaud G. 2015. Copper Metallurgical Slags-Current Knowledge and Fate: A Review. Crit. Revs in Environm. Sci. Techn., vol. 45 (22), 2422-2488.

Pouchou J.L., Pichoir F., 1986. Basic Expression of "PAP" Computation for Quantitative EPMA. In: $11^{\text {th }}$ International Congress on X - ray Optics and Microanalysis (ICXOM) (Eds. J. D. Brown \& R. H. Packwood). Ontario, Canada, p. 249-256.

Prem P.R., Verma M., Ambily P.S. 2018. Sustainable cleaner production of concrete with high volume copper slag. J. Clean. Prod., vol. 193, 43-58.

Rustandi A., Nawawi F.W., Pratesa Y., Cahyadi A. 2018. Evaluation of the sustainability of tin slag in cementitious materials: Mechanical properties and Leaching behaviour. IOP Conf. Series: Mater. Sci. Eng., vol. 299, paper \#012046.

Sarfo P., Wyss G., Ma G., Das A., Young C. 2017. Carbothermal reduction of copper smelter slag for recycling into pig iron and glass. Miner. Eng., vol. 107, 8-19.

Sarrafi A., Rahmati B., Hassani H., Shirazi H. 2004. Recovery of copper from reverberatory furnace slag by flotation. Miner. Eng., vol. 17 (3), 457-459.

De Schepper M., Verle P., Van Driessche I., De Belle N. 2015. Use of Secondary Slags in Completely Recyclable Concrete. J. Mater. Civ. Eng., vol. 27 (5), \#04014177.

Schlesinger M., King M., Sole K., Davenport W. 2011. Extractive Metallurgy of Copper, $5^{\text {th }}$ Ed. Elsevier Ltd., Oxford (UK). 
Shanmuganathan P., Lakshmipathiraj P., Srikanth S., Nachiappan A., Sumathy A. 2008. Toxicity characterization and long-term stability studies on copper slag from the ISASMELT process. Res. Conserv. Recycl., vol. 52 (4), 601-611.

Shanmuganathan P., Lakshmipathiraj P., Kumar S., Sumathy A., Srikanth S. 2012. Stability of Copper Smelter Slag in Sea Water. Env. Progr. \& Sust. Energy, vol. 31 (1), 68-76.

Shi C., Meyer C., Behnood A. 2008. Utilisation of copper slag in cement and concrete. Res. Conserv. Recycl., vol. 52 (10), 1115-1120.

Stirbanovic Z., Markovic Z. 2011. The Effect of Copper bearing Particles Liberation on Copper Recovery from Smelter Slag by Flotation. Separ. Sci. Techn., vol. 46 (16), 2496-2500.

Subramanian K., Themelis N. 1972. Copper recovery by flotation. JOM, vol. 24 (4), 33-38.

USGS 2015. Minerals Yearbook 2015. Copper. U.S. Dept. Interior, U.S. Geological Survey, Oct. 2017 [accessed in June 2018 at https://minerals.usgs.gov/minerals/pubs/commodity/copper/myb1-2015coppe.pdf ].

USGS 2018. Mineral Commodity Summaries. Copper. U.S. Geological Survey, Jan. 2018 [accessed on May 4 at: https://minerals.usgs.gov/minerals/pubs/commodity/copper/mcs-2018-coppe.pdf ].

Vehviläinen J., Jalkanen H. \& Poijärvi J. 2003. Copper in solidified copper smelter slags. Scand. J. Metall., vol. $32(2), 65-70$.

Zhong Y., Wang Z., Guo Z., Tang Q. 2012. Defluidization behaviour of iron powders at elevated temperature: Influence of fluidizing gas and particle adhesion. Powder Technol., vol. 230 (1), 225-233. 